\title{
ANALISIS KONSUMSI ARUS LISTRIK PADA MOBIL MULTI PURPOSE VEHICLE
}

\author{
Hendra Firdaus ${ }^{1}$, Endang Rustendi ${ }^{2}$, Ade Herdiana ${ }^{3}$ \\ Fakultas Teknik Universitas Galuh \\ Jl. R.E Martadinata No. 150 Ciamis \\ hendrafirdaus@gmail.com, tendiendang@gmail.com, adethemox@gmail.com
}

\begin{abstract}
Abstrak
Mobil tidak terbatas hanya pada mesin, namun juga berhubungan dengan sistem kelistrikan untuk menjalankan fungsinya. Listrik diperlukan untuk proses pembakaran yang terdapat pada mobil. Untuk menyimpan sumber energi listrik diperlukan Accu. Arus yang berasal dari Accu yaitu arus searah atau arus DC (Alternating Current) tegangan 12 Volt. Fungsi Accu antara lain; Pada saat mesin mati, Accu berfungsi sebagai sumber tenaga listrik yang berfungsi untuk menghidupkan sistem kelistrikan yang ada pada kendaraan, misalnya lampu sein (lampu tanda belok), klakson (horn), indikator yang ada pada dashboard, lampu kota, lampu kepala dan lain sebagainya. Pada saat mesin masih belum hidup, Accu merupakan sumber tenaga listrik satu-satunya yang digunakan, karena pada saat ini altenator pada kendaraan belum berfungsi. Pada saat melakukan starter menggunakan elektrik starter, baterai juga merupakan satu-satunya sumber listrik yang digunakan untuk menghidupkan atau menjalankan motor starter. Pada saat mesin sudah hidup, maka altenator pada kendaraan sudah berfungsi, sehingga baterai sudah tidak lagi menjadi sumber utama penyedia energi listrik. Namun pada saat mesin hidup baterai masih memiliki fungsi yaitu sebagai penstabil tegangan dari alternator. Mengingat kerja altenator kurang stabil dan bergantung dengan putaran altenator, walaupun pada alternator sudah dilengkapi dengan regulator namun masih memerlukan baterai sebagai penstabil tegangan, tegangan tersebut dialirkan ke sistem kelistrikan yang ada pada kendaraan. Di Indonesia mobil yang jumlah penumpang rata-rata mampu memuat 6 sampai 7 penumpang, adalah jenis MPV merupakan singkatan dari Multi Purpose Vehicle. Penelitian dilakukan pada salah satu jenis mobil MVP yaitu mobil merk Avanza. Sumber listrik utama yang dipakai pada mobil Toyota Avanza yaitu Accu 12 Volt 32 Ah. Dari hasil
\end{abstract}

pengukuran dan perhitungan pada kelistrikan mobil dapat ditarik kesimpulan bahwa dengan sumber listrik utama Accu 12V/32Ah mampu memberi kebutuhan Arus Listrik ke semua beban dengan total arus 102,5 A selama 0,31h sebelum Accu kosong kembali

Kata kunci : Konsumsi; Daya; Mobil; MPV; Accu

\begin{abstract}
The car is not only limited to the engine, but also related to the electrical system to carry out its functions. Electricity is needed for the combustion process in cars. To store the source of electrical energy required Accu. The current that comes from the battery is direct current or DC (Alternating Current) voltage of 12 Volts. Battery functions include; When the engine is off, the battery functions as a source of electric power that functions to turn on the electrical system in the vehicle, such as turn signal lights (turn signals), horns (horns), indicators on the dashboard, city lights, head lights and so on. . When the engine is still not running, the Accu is the only source of electricity that is used, because at this time the alternator on the vehicle is not functioning. When starting using an electric starter, the battery is also the only source of electricity used to start or run the starter motor. When the engine is running, the alternator on the vehicle is functioning, so the battery is no longer the main source of electrical energy. However, when the engine is running, the battery still has a function, namely as a voltage stabilizer from the alternator. Considering the work of the alternator is less stable and depends on the rotation of the alternator, even though the alternator is equipped with a regulator but still requires a battery as a voltage stabilizer, the voltage is supplied to the electrical system in the vehicle. In Indonesia, a car with an average number of passengers capable of carrying 6 to 7 passengers is a type of MPV which stands for Multi Purpose Vehicle. The research was
\end{abstract}


conducted on one type of MVP car, namely the Avanza brand car. The main power source used in the Toyota Avanza is the 12 Volt 32 Ah Accu. From the results of measurements and calculations on car electricity, it can be concluded that with the main power source Accu 12V/32Ah being able to provide Electric Current needs to all loads with a total current of 102.5 A for $0,31 \mathrm{~h}$ before the battery is empty again.

Keywords : Consumption; Power; Car; MPV; battery

\section{Pendahuluan}

Listrik diperlukan untuk proses pembakaran yang terdapat pada mobil. Untuk menyimpan sumber energi listrik diperlukan Accu. Arus yang berasal dari Accu yaitu arus searah atau arus DC (Alternating Current) tegangan 12 Volt. Fungsi Accu antara lain; Pada saat mesin mati, Accu berfungsi sebagai sumber tenaga listrik yang berfungsi untuk menghidupkan sistem kelistrikan yang ada pada kendaraan, misalnya lampu sein (lampu tanda belok), klakson (horn), indikator yang ada pada dashboard, lampu kota, lampu kepala dan lain sebagainya. Pada saat mesin masih belum hidup, accu merupakan sumber tenaga listrik satu-satunya yang digunakan, karena pada saat ini altenator pada kendaraan belum berfungsi. Pada saat melakukan starter menggunakan elektrik starter, accu juga merupakan satu-satunya sumber listrik yang digunakan untuk menghidupkan atau menjalankan motor starter. Pada saat mesin sudah hidup, maka altenator pada kendaraan sudah berfungsi, sehingga Accu sudah tidak lagi menjadi sumber utama penyedia energi listrik. Namun pada saat mesin hidup baterai masih memiliki fungsi yaitu sebagai penstabil tegangan dari alternator. Mengingat kerja altenator kurang stabil dan bergantung dengan putaran altenator, walaupun pada alternator sudah dilengkapi dengan regulator namun masih memerlukan Accu sebagai penstabil tegangan yang akan dialirkan ke sistem kelistrikan pada kendaraan. Penyebab tegangan aki mobil terganggu dan rusak tentu bisa saja disebabkan karena kapasitas air aki yang sudah mulai berkurang. Sehingga, sudah mulai sulit untuk mengalirkan listrik ke ke berbagai mesin dalam mobil. Pada dasarnya tidak semua aki cocok untuk segala tipe mobil. Kalau daya listrik yang bisa dihasilkan aki tersebut terlalu kecil, maka membuat mobil tidak bekerja optimal. Diperlukan suatu pengetahuan untuk menentukan kebutuhan daya listrik yang. tepat pada kendaraan supaya daya listrik selalu siap pada saat kendaraan mulai dihidupkan hingga berjalan dalam situasi apapun. Melihat banyaknya pengguna kendaraan khususnya mobil MPV (Multi Purpose Vehicle) di Indonesia maka penelitian dilakukan terhadap salah satu mobil MPV dengan merk Avanza. Tujuan penelitian ingin mengetahui berapa besar konsumsi arus listrik pada kendaraan MPV khususnya merk Avanza. Ada beberapa mobil Jepang yang memiliki kebutuhan ampere aki yang berbeda. Untuk mobil Toyota Avanza membutuhkan ampere 32Ah. Kemudian untuk Toyota Rush 45 Ah, sedangkan Toyota Agya $35 \mathrm{Ah}$.

\section{KAJIAN LITERATUR}

\section{1 Alternator}

Alternator yang biasa disebut sebagai dinamo ampere adalah sebuah komponen pada mobil yang berfungsi menghasilkan arus listrik bagi semua komponen yang membutuhkan aliran listrik, seperti AC, lampu mobil, dan audio mobil. Tidak hanya itu, alternator juga berfungsi mengisi aki mobil agar tetap berada pada tegangan yang stabil sehingga aki tidak drop. Alternator mobil memanfaatkan prinsip kerja elektromagnetik. Dengan memanfaatkan prinsip tersebut, alternator berperan penting agar komponenkomponen kelistrikan di dalam mobil tetap berfungsi dan memiliki daya listrik yang cukup. Mobil yang tidak dilengkapi alternator akan memiliki performa yang rendah. Saat aki mobil habis, mobil akan mengalami mogok mesin karena tidak memiliki pembangkit energi listrik. pada dasarnya cara kerja alternator adalah mengubah energi mekanik menjadi energi listrik. Caranya dengan mengubah putaran mesin menjadi energi listrik dengan memanfaatkan prinsip kerja elektromagnetik Alternator terhubung ke mesin mobil dengan menggunakan belt atau tali kipas. Saat mesin mobil berputar, belt tersebut juga akan memutar roda pulley pada alternator. Putaran.tersebut dimanfaatkan alternator untuk menghasilkan energi listrik. satu putaran mesin mobil akan menghasilkan dua kali putaran roda pulley pada alternator. Cara kerja alternator mobil adalah menghasilkan arus listrik dari koil stator. Kemudian, arus listrik tersebut diatur oleh IC regulator agar tegangan listrik yang dihasilkan tidak lebih dan bisa digunakan untuk mengisi listrik pada aki mobil. Alternator juga mengandung komponen-komponen penting yang 
mendukung prinsip kerjanya sebagai penghasil energi listrik, yaitu rotor, stator, rectifier, dan regulator.Lalu, dengan fungsi sebagai berikut :

\section{ROTOR}

Rotor adalah bagian yang berputar di dalam stator. Rotor berfungsi untuk menghasilkan medan magnet. Di dalamnya, terdapat kumpulan rotor atau koil rotor yang berfungsi untuk membangkitkan medan magnet. Saat arus listrik dialirkan melalui koil, sebagian kutub-kutub magnet pada core akan terpolarisasi menjadi kutub $\mathrm{N}$ dan sebagian lagi menjadi kutub S. Kutub-kutub pada rotor tersebut dibentuk seperti kerang dan melengkung. Bentuk tersebut memungkinkan rotor berputar di dalam stator. Biasanya, di kedua sisi rotor dipasang sebuah kipas pendingin.

2. STATOR

Stator merupakan kumpulan tembaga yang disusun sehingga rotor bisa berputar di dalamnya. Stator berfungsi menghasilkan arus listrik bolak-balik. Pada umumnya, stator memiliki tiga independen koil yang menginduksi electro motive force (emf).

\section{RECTIFIER}

Apabila terdapat arus bolak-balik yang tidak cocok digunakan pada sistem kelistrikan mobil, arus tersebut harus diubah menjadi searah. Arus bolakbalik yang diinduksi dalam koil stator diubah oleh rectifier. Diode pada rectifier adalah komponen semi konduktor yang mengalirkan arus ke satu arah dan menahan arus yang mengalir dari arah yang berlawanan. Rectifier juga berfungsi menahan arus dari baterai ke alternator jika tegangan yang dihasilkan alternator lebih rendah daripada tegangan baterai

\section{REGULATOR}

Untuk mendapatkan arus dan tegangan yang rata dan stabil, diperlukan regulator. Hal tersebut disebabkan karena tegangan arus listrik yang dihasilkan oleh stator bersifat tidak stabil. Sederhananya, regulator berfungsi mengatur arus listrik yang masuk ke dalam rotor. Jika arus listrik di dalam stator kurang, maka regulator akan menambah listrik ke rotor, namun jika berlebihan, regulator akan mengurangi jumlah listrik yang masuk ke rotor. Nah, dengan demikian, tegangan dan arus listrik yang dihasilkan oleh alternator akan selalu stabil dan konstan.

\section{A. Accumulator}

Accumulator (accu, aki) adalah sebuah alat yang dapat menyimpan energi (umumnya energi listrik) dalam bentuk energi kimia. Contoh akumulator adalah baterai dan kapasitor. Pada umumnya di Indonesia, kata akumulator (sebagai aki atau accu) hanya dimengerti sebagai "baterai" mobil. Sedangkan di bahasa Inggris, kata akumulator dapat mengacu kepada baterai, kapasitor, kompulsator, dll. di dalam standar internasional setiap satu cell akumulator memiliki tegangan sebesar 2 volt. sehingga aki 12 volt, memiliki 6 cell sedangkan aki 24 volt memiliki 12 cell. Aki termasuk sel sekunder, karena selain menghasilkan arus listrik, aki juga dapat diisi arus listrik kembali. secara sederhana aki merupakan sel yang terdiri dari elektrode $\mathrm{Pb}$ sebagai anode dan $\mathrm{PbO} 2$ sebagai katode dengan elektrolit $\mathrm{H}_{2} \mathrm{SO}_{4}$.

Kode aki dituliskan mengikuti dua metode, yaitu:

a. Japan Industrial Standard (JIS), banyak beredar karena sesuai dengan permintaan pasar yang lebih banyak kepada kendaraan Jepang.

\section{Contoh 1: Aki NS40ZLS}

$\mathrm{N}=$ Normal

$\mathrm{S}$ = pengurangan daya aki sebesar $20 \%$

$40=$ daya utama aki

$\mathrm{Z}$ = penambahan daya aki sebesar $10 \%$ setelah dikurangi 20\% (huruf S pertama)

$\mathrm{L}=$ left, artinya pole (kepala aki / kutub negatif) $[-]$ berada di sebelah kiri. Tanpa kode ini pole pasti berada di sebelah kanan.

$\mathrm{S}=$ aki memiliki kutub ukuran besar. Jadi aki NS40ZLS mempunyai daya:

$40 \mathrm{Ah}-20 \%+10 \%=32$ Ah dengan pole sebelah kiri dan kepala aki besar.

Contoh 2: Aki N 40

Daya utama 40Ah

Kepala aki besar, walaupun tidak memiliki kode $\mathrm{S}$ dibelakangnya.Hal ini karena huruf awalnya bukan NS.

Contoh lain:

Aki NS 40: kapasitas 32 Ah

Aki NS 40 Z: kapasitas 35 Ah

Aki NS 40 ZS: kapasitas 35 Ah dengan kepala aki besar

Hendra Firdaus, Endang Rustendi, Ade Herdiana 
Sekarang ini kode di atas mengalami perubahan menjadi lebih simpel. Seperti NS 40 menjadi 32B20R, artinya:

32: kapasitas aktual aki $32 \mathrm{Ah}$

B: kode baterai

20: panjang aki $20 \mathrm{~cm}$

R: posisi pole di sebelah kanan

b. Deutsches Institut für Normung (DIN) banyak digunakan untuk mobil buatan Eropa, menggunakan kode 5 digit angka tapi yang perlu diperhatikan hanya 3 digit angka di depan. Cara membacanya:

Angka pertama : 5 menjadi 0. Angka pertama : 6 menjadi 1 Angka pertama : 7 menjadi 2Contoh: Aki 54533

Angka pertama : 5 menjadi angka 0

Angka kedua \& ketiga 45 = tetap angka 45

Kapasitas aki adalah $045 \mathrm{Ah}=45 \mathrm{Ah}$

Contoh lain: Aki 73530

Kapasitas aki adalah: $235 \mathrm{Ah}$.

Setiap aki punya kode yang bisa dilihat langsung pada aki. Perbedaan standar bisa dilihat pada letak kepala aki (kutub): tenggelam untuk aki tipe DIN dan muncul untuk aki tipe JIS (lebih tinggi).

Kode Produksi Aki Yuasa menggunakan penomoran 7 digit. Dua nomor pertama adalah kode hari, dua angka berikut tanda bulan produksi, dua angka berikut tahun produksi, dan angka terakhir kode negara produksi. Contoh: Kode tanggal 2106049 Artinya aki ini diproduksi hari ke-21, di bulan ke-6, di tahun 2004, dan diproduksi di Indonesia. Sedangkan Aki GS menggunakan 6 digit kode. Contoh: Kode Tanggal 20B4B5 Tanggal produksi di dua nomor pertama. B berarti dibuat pada bulan November. GS memberi kode untuk bulan Januari- September menggunakan angka 1 sampai 9. Untuk OktoberDesember menggunakan kode A sampai C. Angka 4 berarti tahun produksi sedangkan B5, waktu shift dan jalur produksi aki di pabrik.

\section{II.2 Kelistrikan Mobil}

Mobil tidak terbatas pada mesin, tetapi berhubungan juga dengan sistem kelistrikan mobil yang perlu diketahui oleh para pemilik mobil. Meski sifat kelistrikan mobil bukan sebagai bagian utama, tapi mesin mobil membutuhkan listrik untuk menjalankan fungsinya. Listrik diperlukan untuk proses pembakaran yang terdapat pada mobil. Misalnya pada busi, ia hanya akan menyala ketika terkena arus listrik. Jika tidak ada listrik, busi tidak bisa menyala dan jalannya mesin mobil pun terhambat. Jadi dapat disimpulkan bahwa sistem listrik memegang peranan penting dan masalah kelistrikan mobil perlu diperhatikan oleh para pengguna.

Secara definisi, kelistrikan mobil adalah rangkaian listrik yang disusun sedemikian rupa untuk menjalankan fungsi pada mobil. Semua sistem atau fungsi yang membutuhkan energi listrik pada mobil termasuk dalam kelistrikan mobil. Fungsi kelistrikan mobil antara lain menjadi sumber energi pada busi agar bisa menyala, menjalankan mesin, serta meningkatkan performa dan kenyamanan mobil. Sistem Kelistrikan pada mobil terdiri dari :

1) Sistem Kelistrikan Mesin Mobil adalah rangkaian kelistrikan yang ada pada mesin guna membantu kinerja mesin supaya lebih mudah dan efisien dalam bekerja. Seperti yang dijelaskan diatas, contoh sistem kelistrikan mesin adalah busi. Busi dapat menyala ketika ada arus atau energi listrik yang mengubah listrik menjadi api. Setelah terjadi perubahan ini, mesin mobil bisa nyala dan dijalankan, selain busi terdapat sistem kelistrikan mesin mobil lainnya, yaitu:

a. Sistem Starter merupakan bagian dari kelistrikan mesin yang memiliki fungsi dalam proses putaran awal mesin. Ketika terjadi putaran awal yang menyebabkan poros mesin berputar, maka terjadilahi pembakaran pertama mesin.

b. Sistem Pengisian merupakan rangkaian kelistrikan mesin yang menyuplai arus listrik. Fungsinya adalah mengubah sebagian putaran mesin melalui dinamo menjadi energi listrik agar kelistrikannya selalu menyala.

c. Sistem Pengapian berfungsi untuk mengeluarkan percikan api pada sistem tersebut Sistem pengapian memanfaatkan tenaga elektromagnetik guna menaikkan tegangan pada baterai.

d. Glow Plug System (Diesel) merupakan pemanas yang memiliki fungsi untuk menaikkan suhu pada mesin diesel ketika mesin masih dingin. Tujuannya adalah untuk memperlancar proses starting mobil.

e. Sistem Efi atau yang biasa dikenal dengan injeksi merupakan sistem kelistrikan mesin terpadu yang menyuplai bensin ke mesin. Jumlah atau volume bensin yang disuplai ideal untuk semua situasi dan kondisi. 
f. Sistem common rail (diesel) berfungsi untuk mengatur jumlah solar yang disuplai ke ruang pembakaran dengan volume yang pas. sistem ini mirip dengan sistem efi, namun pada common rail dipakai untuk mesin diesel.

2) Sistem Kelistrikan Body Mobil merupakan rangkaian listrik yang terdapat pada bagian body mobil. Meskipun sistemnya berbeda dengan kelistrikan mesin, namun sistem listrik yang digunakan keduanya adalah sama. Beberapa jenis kelistrikan body mobil antara lain:

a. Sistem Penerangan Eksterior merupakan sistem kelistrikan pada bagian luar mobil yang meliputi lampu jauh, lampu kota, serta lampu kabut. Sistem ini berfungsi untuk menerangi bagian eksterior mobil.

b. Sistem penerangan interior merupakan sistem kelistrikan yang berfungsi untuk menerangi bagian dalam mobil, seperti lampu kabin yang bisa dinyalakan baik secara manual maupun otomatis.

c. Sistem peringatan merupakan sistem kelistrikan mobil yang memberikan tanda atau peringatan kepada pengendara lain di jalan. contoh dari sistem peringatan adalah lampu dim, lampu sen, lampu berhenti, serta lampu mundur.

3) Sistem Infotainment Mobil merupakan rangkaian kelistrikan pada mobil yang berfungsi memberikan hiburan pada pengemudi dan penumpang. Beberapa contoh atau jenis dari sistem kelistrikan ini adalah audio, video, dan display.a Multi Info Display. Pada dashboard mobil terdapat sistem kelistrikan yang disebut Multi Info Display atau MID, sistem ini memberikan informasi mengenai kecepatan mobil atau speedometer, indikator bensin, indikator oli, airbag, check engine dan sebagainya. MID sangat penting bagi pengemudi saat berkendara karena memberikan peringatan atau info penting terkait keselamatan dan kenyamanan.

a. Audio dan video merupakan salah satu fitur yang wajib ada pada mobil zaman sekarang. Fungsinya adalah memberikan hiburan serta kenyamanan lebih dalam berkendara. Terlebih di kawasan macet, sistem ini sangat dibutuhkan. Pengguna dapat memutar radio, mendengarkan musik, hingga memutar video selama perjalanan.

b. Usb port dan cigarette lighter berfungsi untuk mengisi daya hp. Dalam hal ini pengemudi dapat mengisi daya ponsel sambil berkendara.
4) Sistem Kelistrikan Chasis Mobil merupakan sistem atau rangkaian kelistrikan mobil yang terdapat pada bagian power train dan chasis mobil. Fungsi dari rangkaian listrik ini adalah untuk mempermudah perpindahan tenaga dari bagian mesin ke roda. Dengan adanya sistem chasis, mobil akan efektif untuk dijalankan dan lebih aman untuk digunakan berkendara. Beberapa contoh atau macam sistem kelistrikan chasis antara lain:

a. Sistem abs dan ebd merupakan sistem kelistrikan yang berfungsi untuk mencegah selip ketika pedal rem diinjak. Sedangkan ebd berfungsi untuk menyalurkan tenaga pengereman. Keduanya membantu fungsi keamanan mobil.

b. Hsa, traction control, stability control berfungsi menjaga keamanan mobil ketika berkendara di medan yang berat seperti jalan yang terjal, menanjak, atau di area pegunungan. Meskipun demikian, hsa hanya ditemukan pada mobil suv saja.

c. Differential clutch berfungsi untuk menyambung atau memutus differential pada kendaraan.

d. Transmission solenoid merupakan sistem kelistrikan mobil yang berfungsi untuk memindahkan gigi dengan menggunakan solenoid.

\section{5) Sistem Keamanan Dan Keselamatan Mobil terdiri dari :}

a. Bag Inflator Control merupakan sistem kelistrikan yang berfungsi untuk mencegah cedera ketika pengemudi mengalami kecelakaan. Jika terjadi benturan, kantong udara atau airbag akan mengembang sehingga kepala pengemudi terhindar dari benturan keras. Selain itu, terdapat bag inflator control pada sistem ini yang mengontrol kapan waktu yang tepat airbag akan mengembang.

b. Immobilizer atau sistem anti maling, pada sistem ini, terdapat kunci kontak yang memancarkan gelombang. Jika kunci yang digunakan tepat, maka mobil bisa dinyalakan. Namun jika kunci tidak cocok, maka mobil tidak akan bisa menyala ketika distarter.

c. Alarm System akan memberikan peringatan ketika ada orang yang hendak berbuat jahat di sekitar mobil, seperti mencuri, merusak, dan sebagainya. Jika ada gangguan fisik pada mobil, otomatis alarm akan menyala.

Dengan adanya sistem kelistrikan pada mobil, mobil akan lebih efisien dan nyaman ketika digunakan. Bagian atau fitur mobil dapat berfungsi 
dengan baik dengan adanya sistem tersebut. Terdapat banyak komponen pada sistem listrik mobil. Yaitu:

a. supply arus, merupakan komponen yang menjadi sumber arus listrik bagi komponen lainnya. Supply arus memiliki 2 bagian utama, yaitu baterai dan alternator. Kedua part ini menyuplai arus bagi komponen mobil lain seperti ac, audio, serta berbagai jenis lampu lainnya. Jumlah baterai dan kapasitas alternator disesuaikan dengan kebutuhan serta fungsi listrik pada mobil. Semakin besar listrik yang dibutuhkan maka jumlah baterai yang digunakan akan semakin banyak.

b. Output, merupakan hasil dari sistem kelistrikan mobil, seperti lampu led, audio, head unit, ac, klakson, dan lain sebagainya. Output juga merupakan sebuah satu kesatuan dengan komponen input.

c. Input. Komponen input mempengaruhi komponen kelistrikan yang lain. Keaktifan seluruh kelistrikan mobil ditentukan oleh komponen input. Komponen input dapat diaktifkan secara manual oleh pengemudi maupun aktif secara otomatis oleh sistem. Komponen input yang perlu diaktifkan secara manual antara lain tombol, knop, switch, serta saklar. Sedangkan komponen yang aktif secara otomatis antara lain sensor dan indikator yang dipengaruhi oleh komputerisasi kendaraan. Nah, ketika komponen input tersebut diaktifkan, maka sistem listrik akan menyala. Begitu juga sebaliknya, ketika komponen input mati, maka sistem kelistrikan akan berhenti. Jadi dapat disimpulkan bahwa komponen input berfungsi untuk menyambung serta memutus aliran listrik ke perangkat.

d. Wiring harness atau rangkaian kabel berfungsi untuk mengalirkan arus dari sumber listrik ke perangkat yang memerlukan. Rangkaian kabel ini saling berkaitan satu sama lain sehingga ketika terjadi kerusakan pada salah satu kabel, maka seluruh komponen kabel harus diganti. Beberapa contoh wiring harness pada kelistrikan mobil antara lain rangkaian ac, audio,serta mesin.

e. Sistem control merupakan salah satu komponen kelistrikan mobil. Komponen ini merupakan komponen wajib pada mobil yang memiliki sistem komputerisasi. Pada mobil jenis ini, rangkaian kelistrikan dihidupkan dan dimatikan dengan prosesor komputer sehingga tidak komponen input tidak dibutuhkan. Contohnya adalah sistem pengereman abs, auto levelling headlamp, transmission control module, dan sejenisnya. Sistem control pada kelistrikan mobil bekerja sendiri secara otomatis, sehingga tidak membutuhkan peran atau kontrol dari pengemudi.

\section{Metode Penelitian}

Penelitian dilakukan dengan cara pengukuran objek yang diteliti dan perhitungan data, dengan cara sebagai berikut :

\section{III.1 Mengukur Besarnya Arus Accu mobil.}

Arus pada Accu mobil biasanya diwakili dengan simbol Ah atau ampere hour. Ah adalah arus listrik maksimal yang dapat dihasilkan Accu dalam durasi satu jam. dari kode pada aki mobil. Misalkan memilih aki dengan spesifikasi 12V, 10Ah. Maka, aki tersebut memiliki tegangan listrik sebesar 12 Volt dan bisa menghasilkan arus listrik maksimal 10 Ampere dalam kurun waktu satu jam sebelum akhirnya habis. Semakin kecil nilai Ah, maka semakin kecil kemampuan aki untuk menahan beban kelistrikan mobil. Arus listrik yang dimaksud di sini berbeda dari daya listrik. Kuat arus memiliki satuan ampere dan menyatakan seberapa besar aliran listrik suatu rangkaian kelistrikan. Sedangkan daya listrik dalam satuan Watt adalah kekuatan yang dibutuhkan perangkat kelistrikan (seperti dinamo starter dan lampu) hingga dapat menyala sempurna

\section{III.2 Menghitung daya listrik pada Accu}

Dengan memahami ampere Accu mobil, maka daya listrik yang dapat dihasilkan aki dapat dihitung dengan menggunakan rumus berikut:

$$
\mathbf{P}=\mathbf{V} \times \mathbf{I}
$$

$\mathrm{P}$ adalah daya listrik, sedangkan $\mathrm{V}$ adalah tegangan Accu dan I mengacu pada arus listrik yang mampu dikeluarkan oleh Accu.

Daya listrik dapat diketahui melalui perkalian tegangan dengan arus.

Misalnya, pada contoh Accu sebelumnya, Accu 12V 10Ah. Maka, Accu tersebut bisa menghasilkan daya listrik sebesar 120 Watt (12V x 10Ah).

Arus listrik yang keluar dari aki tidak hanya terbatas pada Ah, karena Ah hanyalah kapasitas maksimum Accu bertahan sebelum kosong. Accu 12V $10 \mathrm{Ah}$ memang hanya bisa mengeluarkan arus 10 Ampere dalam satu jam, tapi dalam setengah jam jumlahnya bisa bertambah dua kali lipat menjadi 20 Ampere, dan dalam seperempat jam bisa bertambah lagi menjadi 40 Ampere. 


\section{III.3 MENGHITUNG KEBUTUHAN ARUS LISTRIK}

Dengan menjumlahkan semua perangkat listrik yang ada pada mobil maka dapat dihitung kebutuhan arus listriknya, Salah satunya adalah dinamo starter. Misalnya, mobil mempunya dinamo starter dengan daya 2400 Watt. Accu dengan berapa ampere yang bisa digunakan? maka dapat menggunakan rumus berikut:

\section{$\mathbf{I}=\mathbf{P} / \mathbf{V}$}

Jika dinamo starter memiliki daya sebesar 2400 Watt dan tegangan 12 Volt, maka diperlukan arus listrik sebesar 200 Ampere. Untuk aki dengan spesifikasi $12 \mathrm{~V} 10 \mathrm{Ah}$, maka ketahanannya adalah selama 0,05 jam atau 3 menit. Artinya, dinamo starter bisa menyala sempurna selama 3 menit sebelum aki kosong kembali. Selain dengan menggunakan rumus di atas, juga bisa menggunakan beberapa indikator lain untuk mendapatkan ampere aki mobil yang tepat, Yaitu sesuaikan dengan aksesoris kelistrikan. Semakin banyak aksesoris kelistrikan, maka semakin besar ampere yang diperlukan.dan sesuaikan dengan dimensi mesin, semakin besar Ah, biasanya semakin besar dimensi aki. Ada kemungkinan aki tidak bisa terpasang sempurna.

\section{Pembahasan}

\section{IV.1 Mengukur besarnya Arus Accu mobil}

Diketahui Accu mobil Avanza Tegangan 12 Volt dan Kapasitas (muatan listrik) $32 \mathrm{Ah}$.

Pengukuran dilakukan dengan beban terbesar yaitu Dinamo Starter, hasil pengukuran sebesar 200 Ampere.

\section{IV.2 Menghitung Daya Listrik pada Accu.}

Beban terbesar yaitu Dinamo Starter, hasil pengukuran sebesar 2400 Watt.

\section{IV.3 Menghitung Kebutuhan Arus Listrik}

Menghitung kebutuhan arus listrik dilakukan dengan tiga macam situasi dan kondisi dengan pertimbangan bahwa beban yang digunakan secara optimum, yaitu :

a. Pada saat mobil mulai dihidupkan, maka hanya dynamo starter yang bekerja, yaitu sebesar 200A. Untuk Accu dengan spesifikasi 12V/32Ah, ketahanannya adalah selama 0,16 jam atau 9,6 menit. Artinya, dinamo starter bisa menyala sempurna selama 9,6 menit sebelum aki kosong kembali.

b. Pada saat mobil hidup disiang hari dan kondisi hujan, maka komponen yang bekerja sebagai berikut :

Tabel 1. Arus hasil pengukuran saat situasi siang hari dan kondisi hujan.

\begin{tabular}{clc}
\hline NO. & SIRKUIT/KOMPONEN & Arus \\
\hline 1. & Sistem air conditioner. & 7.5 \\
\hline 2. & $\begin{array}{l}\text { Anti-lock brake system, } \\
\text { SRS airbag system, } \\
\text { electric power steering }\end{array}$ & 7.5 \\
\hline 3. & Defogger kaca belakang & 5 \\
\hline & $\begin{array}{l}\text { Sistem injeksi bahan } \\
\text { bakar sequential } \\
\text { multiport, pompa bahan } \\
\text { bakar, kipas pendingin } \\
\text { elektrik }\end{array}$ & 7,5 \\
4. & $\begin{array}{l}\text { Wiper dan Washer kaca } \\
\text { depan }\end{array}$ & 15 \\
\hline Wiper dan Washer kaca \\
belakang
\end{tabular}

Dengan kebutuhan arus 72,5A maka Accu akan bertahan 0,44jam atau 26 menit sebelum Accu kosong Kembali.

c. Pada saat mobil hidup dimalam hari dan kondisi hujan, maka komponen yang bekerja sebagai berikut :

Tabel 2. Arus hasil pengukuran saat situasi malam hari dan kondisi hujan.

\begin{tabular}{|c|c|c|}
\hline NO. & SIRKUIT/KOMPONEN & $\begin{array}{c}\text { Arus } \\
\text { A } \\
\end{array}$ \\
\hline 1. & Sistem air conditioner. & 7.5 \\
\hline 2. & $\begin{array}{l}\text { Anti-lock brake system, } \\
\text { SRS airbag system, electric } \\
\text { power steering }\end{array}$ & 7.5 \\
\hline 3. & Defogger kaca belakang & 5 \\
\hline
\end{tabular}




\begin{tabular}{|c|c|c|}
\hline 4. & $\begin{array}{l}\text { Sistem diagnosis on-board, } \\
\text { meter, system audio }\end{array}$ & 10 \\
\hline 5. & $\begin{array}{l}\text { Lampu kabut (Foglamp) } \\
\text { depan sebelah kanan }\end{array}$ & 7.5 \\
\hline 6. & $\begin{array}{l}\text { Lampu kabut (Foglamp) } \\
\text { depan sebelah kiri }\end{array}$ & 7.5 \\
\hline 7. & $\begin{array}{l}\text { Sistem injeksi bahan bakar } \\
\text { sequential multiport, pompa } \\
\text { bahan bakar, kipas } \\
\text { pendingin elektrik }\end{array}$ & 7,5 \\
\hline 8. & $\begin{array}{l}\text { Wiper dan Washer kaca } \\
\text { depan }\end{array}$ & 15 \\
\hline 9. & $\begin{array}{l}\text { Wiper dan Washer kaca } \\
\text { belakang }\end{array}$ & 15 \\
\hline 10. & Lampu headlamp kanan & 10 \\
\hline 11. & Lampu headlamp kiri & 10 \\
\hline 12. & $\begin{array}{l}\text { Lampu belakang, lampu } \\
\text { posisi depan, lampu plat } \\
\text { nomor. }\end{array}$ & 10 \\
\hline 13. & Electric Power Steering & 20 \\
\hline & T O T A L & 102,5 \\
\hline
\end{tabular}

Dengan kebutuhan arus 102,5A maka Accu akan bertahan 0,31 jam atau 18,7 menit sebelum Accu kosong Kembali.

\section{KESIMPULAN DAN SARAN}

\section{V.1 Kesimpulan}

1) Konsumsi arus listrik yang terbesar adalah pada Dinamo jalan/alternator yaitu sebesar 200A. Apabila dinyalakan terus menerus maka Accu $12 \mathrm{~V} / 32 \mathrm{Ah}$ akan bisa menyala dengan sempurna selama 9,6 menit sebelum aki kosong Kembali.

2) Pada siang hari kebutuhan Arus listrik secara optimal yaitu sebesar 75,5A sedangkan pada malam hari sebesar 102,5A.

3) Apabila Alternator tidak bekerja sehingga tidak ada pengisian ke Accu maka Accu 12V/32A akan bertahan selama 26 menit saat siang hari dan 18,7 menit pada malam hari.

4) Accu pada mobil Avanza 12V/32A sudah bisa memenuhi kebutuhan Arus Listrik dengan ketentuan saat starter tidak lebih dari 9,6 menit.
5) Setiap Accu memiliki kapasitas yang beda-beda, antara lain $32 \mathrm{Ah}, 35 \mathrm{Ah}, 40 \mathrm{Ah}, 45 \mathrm{Ah}$, dan 60 Ah. Arus yang dikeluarkan Accu tergantung besarnya daya listrik yang dibutuhkan tiap beban kelistrikan. Accu 40 Ah atau 60 Ah bisa mengeluarkan arus dengan besar yang sama, tapi Accu 60 Ah bisa lebih tahan lama karena punya kapasitas lebih besar.

\section{V.2 Saran}

1) Betapa pentingna Accu di dalam sistem kerja mobil, sebaiknya sering melakukan perawatan dan pengisian daya secara berkala.

2) Penyebab aki mobil tekor bersumber dari kapasitas Accu yang digunakan hingga jenis Accu. Cara termudah, sesuaikan ampere dengan ampere Accu lama, terutama jika tidak ada penambahan aksesoris kelistrikan.

\section{REFERENSI}

Sudaryono, Widyaiswara Madya "Pengetahuan Tentang Accumulator" Progli Teknik Otomotif PPPPTK BOE Malang, Okt. 2021.

Albert Paul Malvino, Ph.D., E.E, 2003, PrinsipPrinsip Elektronika, Jakarta: Salemba Teknika.

Drs. H. Mustaghfirin Amin, MBA, 2016, Teori Listrik Dasar Otomotif, Malang: PT. Latif Kitto Mahesa .

Phillip Kristanto, 2015, Sistem Kelistrikan Otomotif, Yogyakarta: Garaha Ilmu.

Warsowiwoho. 1986. Sistem Kelistrikan Pada Peralatan. Jakarta: PN.Pradnyaparamita.

Wiranto Arismunandar. 1986. Pedoman Untuk Mencari Sumber Kerusakan, Merawat Dan Menjalankan Kendaraan Bermotor. Jakarta: PN.Pradnyaparamita.

Y. Canny. 1984. Kelengkapan Listrik untuk Otomotif. Bandung: CV. Prakarya.

https://auto2000.co.id/berita-dan-tips/ampere-akimobil\# diakses September 2021.

https://auto2000.co.id/berita-dan-tips/berapa-ampereaki-mobil-dari-kode. diakses September 2021.

http://p4tkboe.kemdikbud.go.id/bbppmpvboe/berita/d etail/pengetahuan-tentang-ccubatteryaccumulator. diakses Oktober 2021.

https://www.qoala.app/id/blog/gayahidup/otomotif/ke listrikan-mobil/. diakses Oktober 2021.

https://www.teknik-otomotif.com/2017/09/fungsibaterai-accu-pada-kendaraan.html.diakses Oktober 2021. 
https://anyflip.com/ljmk/tkui/basic Manual book Avanza. diakses November 2021.

https://bacabrosur.blogspot.com/.2019/04/tipe-

bohlam-lampu-toyota-avanza.html.diakses

November 2021.

https://www.qoala.app/id/blog/gaya hidup/otomotif/ kelistrikan-mobil/. diakses September 2021.

https://daihatsu.co.id/tips-and-event/tips-sahabat/

detail-content/Mengenal-Pentingnya- Alternator-

Mobil/. diakses September 2021. 